BISMA

(Bisnis dan Manajemen)
Volume 11, Nomor 1, Oktober 2018, 77-103

ISSN 2549-7790 (Online)

ISSN 1979-7192 (Print)

https://journal.unesa.ac.id/index.php/bisma/index

\title{
Pengaruh Budaya Organisasi dan Gaya Kepemimpinan \\ Transformasional-Transaksional terhadap Kinerja Karyawan melalui Komitmen Organisasi dan Kepuasan Kerja pada Yayasan Nurul Hayat
}

\author{
Muhammad Yusuf Aria Widjaja ${ }^{1}$, Mukhamad Yasid $^{2}$, Abdurrahman Misno ${ }^{3}$ \\ STEI Tazkia ${ }^{1,2,3}$ \\ Email korespondesi: ariawino@gmail.com
}

\begin{abstract}
Cultural organisation as a system formed by the company management, has the same characteristics than other organisations. It is due to the leader has authority to change the old paradigm to a new transformation. The purposes are employees have a high commitment in organisation, satisfaction at work, and also to improve the performance of the given contribution. The purpose is to examine the Influence of Cultural Organisation and a leader style which is Transformational-Transactional sign to Employee Performance, High Commitment in Organisation, and also the satisfaction at work.. This study applies Structural Equation Modeling (SEM) with 5\% alpha significance. Data is obtained from 116 employees "Nurul Hayat" Foundation with proportional sampling technique by using questionnaires, interviews and documentation. At P-Value (>0,05) and T-Value $(>1,96)$ indicate that, Culture Organisation has positive and significant influence on employee performance, organisation commitment and job satisfaction. The leadership style has positive and significant influences on job satisfaction and organisation commitment. The leadership style has positive and insignificant effects on employee performances. Organisation commitment has positive and insignificant effects on employee performances. Job satisfaction has positive and significant effects on employee performances.
\end{abstract}

Keywords: cultural organisation; employee performance; job satisfaction; organisational commitment; transformational-transactional leadership style

Received: 6 Juli 2018

Reviewed: 20 Agustus 2018

Accepted: 19 September 2018

Published: 31 Oktober 2018

\section{PENDAHULUAN}

Suatu perusahaan dalam melaksanakan kegiatan usahanya selalu ingin mencapai tujuan yang sesuai dengan visi, misi, dan budaya serta strategi yang telah ditetapkan sebelumnya oleh manajemen. Karyawan sebagai insan perusahaan merupakan sumber daya manusia yang memiliki posisi yang sangat 
penting dalam keberhasilan dalam pengelolaan perusahaan untuk mencapai tujuan produktivitas dalam perusahaan tersebut (Petrescu \& Simmons, 2008). Terlebih banyak penelitian melihat sumber daya manusia (SDM) sebagai sarana pendukung nilai tambah yang kompetitif bagi organisasi (Zheng, 2009). Berkembangnya teori ini bermula dari Amerika Serikat dengan negara barat seperti Inggris dan Kanada sebagai pencipta teori sumber daya manusia (Convertino, 2008). Namun, banyak perusahaan yang memperjuangkan teknologi supaya bertahan dan lebih kompetitif daripada harus membayar upah lebih terhadap produktivitas SDM (Wright, 2002). Teori SDM yang dikembangkan di Amerika Serikat ternyata tidak sesuai keberadaanya di dunia dengan keadaan perusahaan di negara Timur Tengah dan Asia (Jamal, 2000).

Nilai-nilai budaya Islam dapat dilakukan oleh seluruh komponen perusahaan termasuk pendiri, pejabat puncak, dan staff, di mana pendiri merupakan kunci utama dalam memilih budaya Islam perusahaannya untuk meningkatkan produktivitas dan kenyamanan demi keberlangsungan perusahaan (Hoque, et.al., 2013). Bahkan dalam penelitian Yousef (2001) menyebutkan bahwa etika pekerja dengan penerapan budaya Islami memiliki penilaian yang baik pada kepuasan kerja dan komitmen organisasi dibandingkan dengan pekerja yang tidak menerapkan budaya Islami tersebut.

Perusahaan dapat mengukur kinerja yang tercakup dalam sistem manajemen secara menyeluruh (baik individu maupun kelompok) sehingga menghasilkan kinerja yang terukur sesuai dengan tujuan perusahaan. Aguinis (2011) berpendapat bahwa manajemen kinerja adalah suatu proses pengelolaan yang berkelanjutan yang meliputi identifikasi, mengukur dan membangun kinerja individu dan kelompok sehingga kinerja tersebut harus selaras dengan pencapaian tujuan strategik perusahaan.

Terkait budaya dan kinerja dalam penelitian Uddin, et.al. (2013) menjelaskan bahwa hubungan ukuran kinerja dan budaya dapat dipahami dengan cara yang sama artinya ukuran kinerja harus memanfaatkan kelembaman kultur organisasi. Sukmawati (2015) menyebutkan bahwa budaya organisasi berperan dalam hal mengarahkan perilaku, memberi pengertian akan tujuan organisasi, dan membuat mereka berpikiran positif terhadap organisasi.

Dadie, et.al.. (2016) menyatakan bahwa pekerja dengan komitmen yang tinggi akan lebih berorientasi pada kerja. Disebutkan pula bahwa pekerja yang memiliki komitmen organisasi tinggi akan cenderung senang membantu dan dapat bekerja sama. Tingginya komitmen karyawan ditentukan berdasarkan lamanya periode waktu bekerja pada perusahaan dan terdapat hubungan yang positif antara tingkat komitmen karyawan dengan masa kerja (dalam Budiarto, 2004).

Badan Pusat Statistik mencatat bahwa jumlah total populasi penduduk Indonesia pada tahun 2015 sekitar +/-255 juta penduduk. Populasi ini menempatkan Indonesia sebagai negara dengan jumlah penduduk terbesar 
keempat di dunia. Hingga tahun 2019, BPS memprediksi Indonesia akan mengalami kenaikan jumlah penduduk 1,3\%. Dampak dari kenaikan jumlah penduduk tersebut adalah sebesar 32\% masyarakat Indonesia lebih memilih status pekerjaan sebagai buruh/ karyawan di perusahaan baik swasta maupun BUMN.

Bertumbuhnya minat masyarakat Indonesia menjadi seorang karyawan pada suatu perusahaan, akan seiring dengan pertumbuhan jumlah perusahaan atau organisasi syariah-konvensional di Indonesia yang semakin meningkat. Berkembangnya organisasi syariah di Indonesia akan menjadi sebuah peluang untuk membentuk ciri budaya perusahaan syariah yang berbeda, baik dalam segi visi maupun misi pada perusahaan. Penelitian ini tidak hanya berorientasi pada organisasi profit-nonprofit saja, tetapi juga bagaimana model organisasi dalam konsep yang islami dapat terbentuk. Berikut adalah organisasi profit-nonprofit syariah yang berada di Indonesia.

Berdasarkan data dari Otoritas Jasa Keuangan (2017), organisasi profitnonprofit syariah yang berada di Indonesia terdiri dari 1.837 Bank Umum Sariat, 341 Unit Usaha Sariat, 58 Asuransi Sariat (Jiwa, Umum, Reasuransi), 45 Lembaga Pembiayaan Sariat, 9 Lembaga Jasa Keuangan Khusus Sariat dan 18 Lembaga Keuangan Mikro Sariat. Sedangkan untuk Lembaga Amil Zakat menurut Badan Amil Zakat Nasional (2017) terdiri dari 17 Lembaga Amil Zakat Nasional (LAZNAS), 7 Lembaga Amil Zakat Provinsi, dan 16 Lembaga Amil Zakat Kabupaten/ Kota.

Adanya organisasi syariah baik skala profit atau non profit di Indonesia juga menjadi rujukan dalam penelitian ini, yakni dalam hal menilai kemampuan karyawan dalam menjunjung nilai-nilai syariah dan mengaktualisasikan kinerja karyawan di perusahaan. Pemahaman tentang nilai-nilai syariah seorang karyawan dalam perusahaan dalam penelitian ini merujuk pada karyawan Yayasan Nurul Hayat (NH).

Yayasan ini merupakan organisasi non-profit yang berdiri pada tahun 2001 dan Lembaga Amil Zakat Nasional (LASZNAS) berdasarkan SK Menteri Agama RI No. 422 tahun 2015 yang bergerak dalam bidang layanan sosial dan dakwah. NH didirikan dengan cita-cita menjadi suatu lembaga milik ummat yang mandiri dan memberikan gaji karyawan $100 \%$ tidak mengambil dana donasi zakat, infak dan shodaqoh (ZIS). Usaha mandiri Yayasan di antaranya adalah aqiqah, percetakan, tour and travel dan usaha lainnya. NH berkantor pusat di kota Surabaya dan telah memiliki 23 Kantor Perwakilan antara lain Surabaya Barat, Sidoarjo, Malang, Kediri, Tuban, Gresik, Madiun, Bojonegoro, Jember, Bayuwangi, Semarang, Yogyakarta, Solo, Tangerang Selatan, Jakarta, Bandung, Bogor, Balikpapan, Medan, Makassar, Bekasi, Depok, dan Cikarang.

Untuk menyatukan prinsip karyawan, sejak 2014, NH memberlakukan sarana untuk menciptakan budaya islami melalui program Gerakan Ihyaus Sunnah (GIS). GIS dibentuk dengan tujuan untuk merefleksikan sunnah harian Nabi 
Muhammad SAW secara berjamaah kepada para karyawan, donatur, dan masyarakat. Terdapat 10 sunah harian yang harus dilaporkan melalui aplikasi android, di antaranya; Shalat Dhuha, sedekah subuh, Shalat Sunah Rawatib, Qiyamul Lail, puasa sunah, zikir pagi, salat berjamaah di Masjid bagi laki-laki, baca Al-Qur'an, amalan sebelum tidur, dan menjaga wudu.

Program GIS merupakan implementasi budaya organisasi pada NH. Program sunnah harian ini diharapkan dapat mendorong umat muslim dalam meningkatkan kewajibannya dalam menjalankan perintah-Nya dan menjauhi larangan-Nya. Tujuannya antara lain untuk meningkatkan kedekatan para ummat kepada Allah SWT dan dapat berkomitmen kepada pekerjaannya sebagai santri khidmat (karyawan) Yayasan Nurul Hayat.

Dengan adanya gaya kepemimpinan bersifat transformasional, Yayasan Nurul Hayat diharapkan dapat menciptakan adanya perubahan diri karyawan untuk menjadi seorang pemimpin yang saling berkontribusi dengan karyawan lainnya. Secara transaksional, pengamalan GIS ini merupakan salah satu bentuk penghargaan yang diberikan NH kepada karyawan sebagai penghargaan berupa tunjangan ubudiyah, yaitu pemberian tunjangan bagi setiap karyawan yang mampu mengerjakan sunnah harian selama satu bulan penuh pada masa kerja. Manajemen berkomitmen bertujuan untuk menekan turnover, sehingga akan menciptakan nilai kepuasan kerja atas target yang telah diberikan untuk tetap bekerja di lembaga non-government organisation (NGO).

Dengan demikian hasil capaian individu pada indikator kinerja dinilai dapat berpengaruh terhadap pencapaian kinerja secara korporasi melalui pemahaman tentang visi, misi dan komitmen pada yayasan Yayasan Nurul Hayat. Selain itu, dengan adanya GIS dapat menjadi suatu dorongan kuat untuk menciptakan calon pemimpin yang mampu memberikan kontribusi melalui perubahan secara inovatif dan dapat mengapresiasi kinerja karyawannya.

Berdasarkan latar belakang yang telah dipaparkan di atas, penulis mengajukan rumusan masalah sebagai berikut: (1) bagaimana budaya organisasi berpengaruh terhadap komitmen organisasi, kepuasan kerja dan kinerja karyawan pada Yaya1san Nurul Hayat?; (2) bagaimana gaya kepemimpinan berpengaruh terhadap komitmen organisasi, kepuasan kerja dan kinerja karyawan pada Yayasan Nurul Hayat?; (3) bagaimana komitmen organisasi berpengaruh terhadap kinerja karyawan pada Yayasan Nurul Hayat? dan (4) bagaimana kepuasan kerja berpengaruh terhadap kinerja karyawan pada Yayasan Nurul Hayat?

Hasil penelitian ini diharapkan: (1) dapat digunakan sebagai bahan pengembangan ilmu pengetahuan di bidang sumber daya insani, yang terkait dengan pelaksanaan operasional perusahaan syariah maupun konvensional yang dapat dijadikan sebagai role model human resource development; (2) sebagai bahan kajian empiris dan sarana program pendukung pada bidang sumber daya insani dalam memecahkan masalah terhadap pola pikir secara islami terhadap 
problematika di ruang lingkup perusahaan dan (3) bahwa manajemen Yayasan Nurul Hayat dapat menyusun strategi dan mengidentifikasi penyebab sumber daya insani dalam mengantisipasi terjadinya masalah yang disebabkan oleh gaya kepemimpinan, budaya organisasi, komitmen organisasi dan kepuasan terhadap kinerja karyawan.

\section{Budaya Organisasi}

Pemahaman manajemen perusahaan terhadap budaya organisasi menilai bahwa, komponen yang meliputi adat istiadat, tradisi, dan prosedur yang memuat segala aktivitas karyawan lebih menyenangkan dan dapat meningkatkan produktivitas kerja. Pola asumsi dasar adanya budaya organisasi yang ditemukan oleh kelompok tertentu dalam mengatasi permasalahan dengan mengadaptasi lingkungan eksternal maupun internal (Schein, 2004). Janićijević (2013) menjelaskan, budaya akan menciptakan kerangka organisasi dimana pertimbangan dan penalaran manajemen yang tepat menjadi sebuah proses pengambilan keputusan mengenai model struktur organisasi. Ovidiu-Iliuta (2014) menambahkan bahwa unsur utama yang membantu mencapai kinerja yang baik adalah mengembangkan budaya organisasi yang kuat. Selain itu, budaya bahkan dapat mewakili penghalang ketika mencoba menerapkan strategi baru. Sedangkan budaya perusahaan secara islami adalah kepercayaan dan nilai-nilai islami yang mewarnai seluruh pola, perilaku, sikap dan aturan-aturan dalam suatu perusahaan (Fahmi, et.a., 2014) Penelitian ini menggunakan indikator-indikator budaya organisasi menurut Robbins \& Judge (2009) dengan mengkombinasikan pada program Gerakan Ihyaus Sunnah pada Yayasan Nurul Hayat sebagai cerminan budaya organisasi melalui indikator sebagai berikut: (1) innovation and risk taking; (2) attention to detail; (3) outcome orientation; (4) people orientation; (5) team orientation; (6) aggressiveness; (7) stability; dan (8) program gerakan ihyaus sunnah.

\section{Gaya Kepemimpinan Transformasional-Transaksional}

Kepemimpinan adalah kemampuan untuk memutuskan apa yang harus dilakukan dan kemudian membuat orang lain ingin melakukannya (McCloskey, 2015). Berbeda dengan Dartey-Baah (2015: 100) mendefinisikan seorang pemimpin adalah sebagai seorang pria yang memiliki kemampuan untuk membuat orang lain melakukan apa yang tidak ingin mereka lakukan dan apa yang mereka suka. Diantara teori kepemimpinan menurut para ahli, penelitian ini berfokus pada gaya kepemimpinan transformasional dan transaksional yang merupakan variabel dalam penelitian ini.

Odumeru \& Ifeanyi $(2013,356)$ menjelaskan, pemimpin transformasional merupakan seorang pemimpin yang mampu membuat para pengikutnya menghasilkan pekerjaan yang luar biasa diluar target yang diberikan. Kepemimpinan transformasional melambangkan gaya kepemimpinan ideal yang 
diharapkan oleh setiap pemimpin dan anggota organisasi dalam capaian hasil pada kepuasan kerja karyawan (Ngadiman et al., 2013). Menurut Mondiani (2014: 47), kepemimpinan transformasional merupakan kemampuan untuk memberikan inspirasi dan memotivasi para pengikutnya untuk mencapai hasil-hasil yang lebih besar daripada yang direncanakan secara orisinil dan untuk imbalan internal. Adapun empat indikator komponen teori gaya kepemimpinan transformasional yang digunakan dalam penelitian ini menurut Warrilow (2009), yakni: (1) kharisma; (2) motivasi inspiratif; (3) stimulasi intelektual; dan (4) perhatian secara personal/ individual.

Sedangkan, dalam penelitian Bass (2003: 208) mengemukakan bahwa kepemimpinan transaksional yang didefinisikan sebagai kepemimpinan yang melibatkan suatu proses pertukaran yang menyebabkan bawahan mendapat imbalan serta membantu bawahannya mengidentifikasikan perilaku untuk memenuhi hasil yang diharapkan seperti kualitas pengeluaran yang baik, penjualan atau pelayanan yang lebih terhadap karyawan. Kepemimpinan transaksional juga dijelaskan oleh Yukl (2013: 322) yaitu kepemimpinan transaksional dapat melibatkan nilai-nilai, tetapi nilai-nilai tersebut relevan dengan proses pertukaran seperti kejujuran, tanggung jawab, dan timbal balik. Dari dua definisi kepemimpinan transaksional yang diberikan, kita dapat mendifinisikan bahwa kesepakatan yang didasarkan pada nilai kontrak perjanjian antara pimpinan dan anggota mengharuskan anggota mengikuti perintah pemimpin dan diberikan imbalan dalam menyelesaikan tugasnya sebagai motivasi kerja anggota (Penn, 2015). Kepemimpinan transaksional yang digunakan dalam penelitian ini adalah menurut Bass et al., (2003: 210) terbentuk oleh beberapa faktor, antara lain: (1) contingent reward; (2) active management by exception; dan (3) passive management by exception.

\section{Komitmen Organisasi}

Pengertian komitmen organisasi adalah apa yang dikemukakan oleh Durkin (1999:127), bahwa komitmen organisasi merupakan perasaan yang kuat dan erat dari seseorang terhadap tujuan dan nilai suatu organisasi dalam hubungannya dengan peran mereka terhadap upaya pencapaian tujuan dan nilai-nilai tersebut. Adapun pendapat lain terkait komitmen organisasi yaitu "the relative strength of an individual's identification with and involvement in a particular organization" (Mowday et al, 1982, 27). Kemudian menurut Noordin et. Al (1972, 118) mengemukakan pengertian komitmen organisasi adalah "a structural phenomenon which occurs as a result of individual-organizational transactions and alterations in side-bets or investments over time," Tiga dimensi komitmen organisasional yang akan digunakan dalam penelitian ini Puspitawati, $(2013,21)$ yaitu affective commitmen, continuance commitment, dan normative commitment. 


\section{Kepuasan Kerja}

Menurut Mathis \& Jackson (2011: 121), mendefinisikan kepuasan kerja adalah keadaan emosional yang positif yang merupakan hasil dari evaluasi pengalaman kerja seseorang. Kemudian Amstrong (2006: 264), mengemukakan bahwa kepuasan kerja merujuk kepada sikap dan perasaan seseorang terhadap pekerjaan mereka. Sikap positif dan kondusif terhadap pekerjaan menunjukkan kepuasan kerja. Berbeda dengan Squires, et.al. (2015) berpendapat bahwa karyawan yang tidak puas dapat berdampak pada layanan, lingkungan kerja, serta kualitas kinerja yang memiliki kecenderungan menampilkan permusuhan pada karyawan lain di tempat kerja. Dalam Mangkunegara (2013:117), mendefinisikan kepuasan kerja "is the way an employee feels about his or her job". Dalam penelitian Robbins dan Judge (2009:119), menyatakan ada lima faktor kepuasan kerja yang digunakan dalam penelitian ini, diantaranya: (1) kepuasan terhadap pekerjaan; (2) kepuasan terhadap imbalan; (3) kepuasan terhadap supervisi atasan; (4) kepuasan terhadap rekan kerja; dan (5) kesempatan promosi.

\section{Kinerja Karyawan}

Bangun (2012:231) mengatakan kinerja adalah hasil pekerjaan yang dicapai seseorang berdasarkan persyaratan-persyaratan pekerjaan, persyaratan biasa disebut dengan standar kerja yaitu tingkat yang diharapkan suatu pekerjaan tertentu untuk dapat diselesaikan dan diperbandingkan atas tujuan atau target yang ingin dicapai. Kinerja pekerjaan dapat digambarkan sebagai kemampuan individu untuk mencapai tujuan kerja karyawan sesuai dengan capaian ekspektasi dan tujuan organisasi (Gharib, et. al., 2016). Wang et al., (2015) mengatakan bahwa kinerja karyawan adalah subjek yang memiliki peranan penting dalam mencapai hasil kinerja organisasi. Unsur-unsur penilaian kinerja dalam penelitian ini menurut Hasibuan (2005:56), kinerja pegawai dapat dikatakan baik atau dapat dinilai dari beberapa hal, yakni: (1) kesetiaan; (2) prestasi kerja; (3) kedisiplinan; (4) kreativitas; (5) kerja sama; (6) kecakapan dan (7) tanggungjawab.

\section{Hubungan antar Variabel}

Hubungan variabel-variabel dalam penelitian ini ditunjukkan pada gambar 1. Secara rinci, hubungan tersebut dapat dirumuskan dalam hipotesis di bawah ini.

$\mathrm{H}_{1}$ : Budaya organisasi berpengaruh terhadap komitmen organisasi.

$\mathrm{H}_{2}$ : Budaya organisasi berpengaruh terhadap kepuasan kerja.

$\mathrm{H}_{3}$ : Budaya organisasi berpengaruh terhadap kinerja karyawan.

$\mathrm{H}_{4}$ : Gaya kepemimpinan berpengaruh terhadap komitmen organisasi.

$\mathrm{H}_{5}$ : Gaya kepemimpinan berpengaruh terhadap kepuasan kerja.

$\mathrm{H}_{6}$ : Gaya kepemimpinan berpengaruh terhadap kinerja karyawan.

$\mathrm{H}_{7}$ : Komitmen organisasi berpengaruh terhadap kinerja karyawan.

$\mathrm{H}_{8} \quad$ : Kepuasan kerja berpengaruh terhadap kinerja karyawan. 


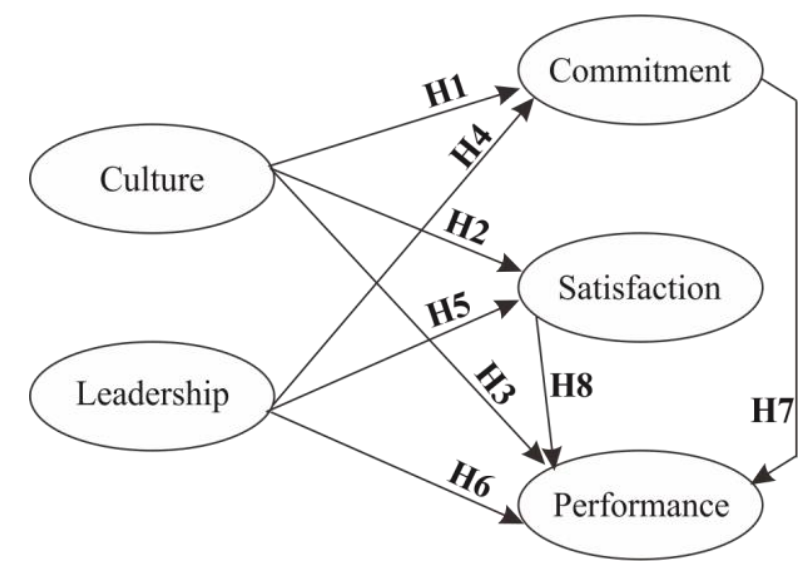

Sumber: Diolah penulis.

Gambar 1. Kerangka Konseptual Penelitian

Berdasarkan latar belakang dan rumusan masalah yang telah dikemukakan dalam perumusan hipotesis dan kerangka konseptual penelitian maka penulis mempunyai beberapa hipotesis yang diuji antara lain sebagai berikut.

\section{METODE PENELITIAN}

\section{Rancangan Penelitian}

Berdasarkan permasalahan yang telah dikemukakan, penelitian ini termasuk jenis penelitian deskriptif kuantitatif dalam (Silalahi, 2010) yakni, penelitian yang bersifat deskriptif bertujuan menggambarkan secara tepat sifat-sifat individu, keadaan, gejala, atau kelompok tertentu, atau untuk menentukan frekuensi atau penyebaran suatu gejala atau frekuensi adanya hubungan antara suatu gejala dan gejala lain dalam masyarakat.

Hal ini dikarenakan penelitian deskriptif kuantitatif menggunakan cara menggambar variabel bebas, variabel terikat, dan membuktikan pengaruh dari variabel bebas terhadap variabel terikat melalui pengujian hipotesis melalui teknik analisis data yang digunakan. Metode yang digunakan dalam penelitian ini adalah metode survey, yaitu metode pengumpulan data dengan mengambil sampel dari populasi dan menggunakan kuesioner sebagai instrumen pengumpulan data utama (Sugiyono, 2010).

\section{Teknik Pengumpulan Data Penelitian}

Rujukan penelitian ini diperoleh dari populasi sebanyak 493 karyawan yang bertugas di Kantor Pusat, 19 Kantor Perwakilan dan beberapa mitra usaha pada Yayasan Nurul Hayat. Selanjutnya dalam (Santosa, 2002) besarnya sampel bila terlalu besar akan menyulitkan untuk mendapatkan model yang cocok. Metode pengukuran SEM disarankan menggunakan ukuran sampel antara 100-200 responden. 
Sampel diambil dengan teknik proporsional sampling, yaitu teknik pengambilan sampel yang menggunakan populasi berstrata, populasi area ataupun populasi cluster. Penggunaan teknik ini dapat dilakukan secara perwakilan berimbang dengan memperhitungkan besar kecil unit-unit populasi yang ada sehingga sampel yang diambil berdasar pada wakil dari unit-unit tersebut (Bungin, 2011). Kuisioner dalam penelitian ini menggunakan skala Likert untuk mengukur sikap, pendapat dan persepsi seseorang atau kelompok tentang fenomena sosial (Kuncoro, 2001).

Kuesioner disebarkan pada 200 karyawan. 116 data kuesioner dari karyawan terkumpul. Ukuran pengambilan sampling akan menyesuaikan pada data populasi perusahaan sebagai acuannya.

\section{Teknik Analisis Data}

Analisis penelitian ini menggunakan model pengukuran dataset Confirmatory Factor Analysis (CFA) dan Structural Equational Modelling (SEM) pada Lisrel 8.80 pada pengujian $\mathrm{H}_{1}$ hingga $\mathrm{H}_{8}$. Analisis dilakukan menggunakan Structural Equation Modeling (SEM) dengan signifikan alpha 5\%. SEM terdiri dari 2 model yaitu model variabel laten dan model pengukuran. SEM merupakan teknik analisis multivariat yang memungkinkan peneliti untuk menguji hubungan antara variabel yang kompleks untuk memperoleh gambaran menyeluruh mengenai keseluruhan model. SEM dikembangkan untuk menutupi keterbatasan yang dimiliki oleh model-model seperti analisis regresi, path analysis (analisis jalur), dan confirmatory factor analysis (analisis faktor konfirmatori). Komponenkomponen model SEM terdiri dari dua jenis variabel yaitu latent variables dan observed/measured/manifest variables, dua jenis model yaitu structural model dan measurement model serta dua jenis kesalahan, yaitu structural error dan measurement error.

\section{Variabel Laten}

Dalam SEM variabel kunci yang menjadi perhatian adalah variabel laten. Variabel laten memiliki konsep abstrak, sebagai contoh: kesejahteraan, spiritual, perilaku, dsb. Variabel laten ini hanya dapat diamati secara tidak langsung dan tidak sempurna melalui efeknya pada variabel teramati. SEM memiliki 2 jenis variabel laten yaitu eksogen (variabel bebas pada semua persamaan yang ada dalam model) dan endogen (variabel terikat pada paling sedikit satu persamaan dalam model). Notasi matematik dari variabel laten eksogen adalah huruf yunani $\xi$ (ksi) dan variabel laten endogen ditandai dengan $\eta$ (eta).

Simbol dari variabel laten adalah lingkaran atau elips. Simbol untuk menunjukkan hubungan kausal adalah anak panah. Variabel laten eksogen digambarkan sebagai lingkaran dengan semua anak panah menuju keluar. Variabel laten endogen digambarkan sebagai lingkaran dengan paling sedikit satu 
anak panah masuk ke lingkaran, meskipun anak panah lain menuju keluar dari lingkaran.

\section{HASIL DAN PEMBAHASAN}

Analisis uji SEM pada penelitian ini ditunjukan hasil analisis dengan menggunakan beberapa prosedur pada uji SEM dimulai dari tahap speksifikasi, identifikasi, estimasi, dan uji kecocokan. Berikut adalah hasil dari keseluruhan prosedur uji SEM yang diperoleh (Masrifah, 2017),

\section{Tahap Spesifikasi}

Tahap pertama adalah spesifikasi model. Tahap spesifikasi adalah dengan membuat spesifikasi model pengukuran, spesifikasi model struktural, dan gambar path. Tahap ini berhubungan dengan pengembangan hipotesis sebagai dasar dalam menghubungkan variabel laten dengan variabel laten lainnya, dan juga dengan indikator-indikatornya. Dengan kata lain, model yang dibentuk adalah persepsi kita mengenai bagaimana variabel laten dihubungkan berdasarkan teori dan bukti yang kita peroleh dari disiplin ilmu. Konseptualisasi model ini juga harus merefleksikan pengukuran variabel laten melalui berbagai indikator yang dapat diukur. Dalam tahap spesifikasi terdiri dari model pengukuran, persamaan structural model dan path diagram.

Model pengukuran yang paling umum dalam aplikasi SEM ialah model pengukuran non-generik, di mana setiap ukuran atau variabel teramati hanya berhubungan dengan satu variabel laten dan semua kovariasi di antara variabelvariabel teramati adalah sebagai efek dari hubungan antara variabel teramati dan variabel laten.

Model struktural merupakan hubungan-hubungan yang ada di antara variabel-variabel laten. Hubungan-hubungan ini umumnya linear, meskipu tidak menutup kemungkinan SEM memiliki hubungan non-linear. Sebuah hubungan di antara variabel-variabel laten serupa dengan sebuah persamaan regresi linear di antara variabel laten. Beberapa persamaan regresi linear tersebut membentuk sebuah persamaan simultan variabel-variabel laten.

\section{Tahap Identifikasi}

Sebelum melakukan tahap estimasi untuk mencari solusi dari persamaan struktural yang mewakili model yang dispesifikasikan, terlebih dahulu perlu mengidentifikasi persamaan struktural tersebut. Secara garis besar ada 3 kategori identifikasi dalam persamaan structural, yaitu overidentified, justidentified, dan underidentified.

Tahap identifikasi dilakukan dengan membandingkan jumlah data yang diketahui dengan jumlah parameter. Jumlah data yang diketahui adalah jumlah varian dan kovarian antara variabel teramati (observed/manifest); yang merupakan 
hasil dari $=((\mathrm{p}+\mathrm{q}) *(\mathrm{p}+\mathrm{q}+1)) / 2$, dimana $\mathrm{p}=\mathrm{jml}$ variabel y (indikator laten endogen) dan $\mathrm{q}=\mathrm{jml}$ variabel $\mathrm{x}$ (indikator laten eksogen). Jika jumlah data yang diketahui > jumlah parameter, maka model tersebut adalah over-identified. Overidentified, merupakan model yang diharapkan, karena jumlah persamaan yang tersedia melebihi jumlah parameter yang diestimasi. Jika jumlah data yang diketahui sama dengan jumlah parameter, maka model tersebut adalah justidentified, sehingga solusi yang unik, tunggal, dapat diestimasi untuk mengestimasi parameter. Jika jumlah data yang diketahui < jumlah parameter, maka model tersebut adalah under-identified.

Jadi total parameter yang akan diestimasi sejumlah 66; sementara jumlah data yang diketahui, yaitu $(\mathrm{p}=15 ; \mathrm{q}=12,(\mathrm{p}+\mathrm{q}) *(\mathrm{p}+\mathrm{q}+1)=756 / 2=378)$; Sehingga data $>$ parameter, yang artinya model sudah over-identified (model yang diharapkan).

\section{Tahap Estimasi}

Ukuran sampel pada penelitian ini menggunakan estimasi maximum likelihood dengan sampel adalah sebesar 100-200 dimana sampling yang diberikan sebanyak 116 responden. Metode estimasi yang paling popular digunakan pada penelitian SEM, dan secara default digunakan oleh Lisrel adalah maximum likelihood (ML). Maximum likelihood akan menghasilkan parameter yang valid, efisien dan reliable apabila data yang digunakan adalah multivariate normality (normalitas multivariasi) dan akan robust (tidak terpengaruh/kuat) terhadap penyimpangan multivariate normality yang sedang (moderate). Tetapi estimasi pada ML akan bias apabila pelanggaran terhadap multivariate normality sangat besar. Ukuran sampel yang disarankan untuk penggunaan estimasi maximum likelihood adalah sebesar 100-200. Kelemahan dari metode ML ini adalah ML akan menjadi "sangat sensitif" dan menghasilkan indeks goodness of fit yang buruk apabila data yang digunakan adalah besar (400-500).

\section{Tahap Uji Kecocokan}

Tahap estimasi di atas menghasilkan solusi yang berisi nilai akhir dari parameter-parameter yang diestimasi. Dalam tahap ini, kita akan memeriksa kecocokan antara data dengan model, validitas dan realibilitas model pengukuran dan signifikansi koefisien-koefisien ari model struktural. Langkah uji kecocokan ini merupakan langkah yang banyak memiliki perbedaan pendapat.

Evaluasi terhadap kecocokan model dilakukan melalui beberapa tingkatan, yaitu: (1) analisis atau kecocokan keseluruhan model (overall model fit); (2) analisis atau kecocokan model pengukuran (measurement model fit); dan (3) analisis atau kecocokan model struktural (structural model fit).

Hasil uji kecocokan keseluruhan model (overall model fit) tertera pada tabel 1, dengan indikator overall model fit yang sering digunakan antara lain: uji 
statistik chi-square $\left(\chi^{2}\right)$, root mean square error od approximation (RMSEA), dan goodness of fit index (GFI)

Tabel 1. Ikhtisar Goodness of Fit Statistics

\begin{tabular}{cccc}
\hline Ukuran GOF & Cut-off Value & Hasil Analisis & Evaluasi Model \\
\hline$p$-value & p-value $\geq 0,05$ & 1,00 & Good Fit \\
\hline RMSEA & RMSEA $\leq 0,08$ & 0,00 & Good Fit \\
\hline NFI & NFI $\geq 0,90$ & 1,00 & Good Fit \\
\hline NNFI & NNFI $\geq 0,90$ & 1,03 & Good Fit \\
\hline CFI & CFI $\geq 0,90$ & 1,00 & Good Fit \\
\hline Standardized $R M R$ & SRMR $\leq 0,05$ & 0,33 & Marjinal Fit \\
\hline GFI & GFI $\geq 0,90$ & 0,72 & Marjinal Fit \\
\hline AGFI & AGFI $\geq 0,90$ & 0,67 & Marjinal Fit
\end{tabular}

Sumber: data diolah

Berdasarkan tabel 1, dapat diambil kesimpulan bahwa kecocokan kesuluruhan model diatas menunjukkan adjusted goodeness-of-fit index (AGFI), dan untuk goodness of fit index (GFI) menunjukkan marginal fit atas representasi model dari ukuran target kecocokan yang diberikan. Sedangkan p-value, root mean square error od approximation (RMSEA), normed model fit index (NFI), non-normed model fit index (NNFI) dan comparative fit index (CFI) menunjukkan good fit atas representasi model dari ukuran target tingkat kecocokan yang diberikan.

Bagian kecocokan model pengukuran (measurement model fit) ini menampilkan hasil analisis validitas dan reliabilitas yang disajikan dalam Lisrel 8.70. Nilai-nilai validitas terdiri dari nilai standardized factor loadings (SFL) dan error variance. Sedangkan reliabilitas terdiri dari construct reliability dan variance extracted. Tabel 2 menunjukkan hasil reliabilitas.

Tabel 2. Ikhtisar Reliabilitas

\begin{tabular}{cccc}
\hline Variabel & $* \mathbf{C R} \geq \mathbf{0 , 7}$ & $* \mathbf{V E} \geq \mathbf{0 , 5}$ & Kesimpulan \\
\hline Budaya Organisasi & 0,99 & 0,94 & Reliabilitas Baik \\
\hline Gaya Kepemimpinan & 0,99 & 0,96 & Reliabilitas Baik \\
\hline Komitmen Organisasi & 0,93 & 0,88 & Reliabilitas Baik \\
\hline Kepuasan Kerja & 0,98 & 0,91 & Reliabilitas Baik \\
\hline Kinerja Karyawan & 0,99 & 0,93 & Reliabilitas Baik \\
\hline
\end{tabular}

Sumber: data diolah

Pada hasil kecocokan model struktural (structural model fit), diagram lintasan pada gambar 4 untuk solusi standard dan T-Value yang menunjukkan hubungan kausal antar variabel penelitian sesuai dengan model yang diberikan. Evaluasi model struktural berkaitan dengan pengujian hubungan antarvariabel yang sebelumnya dihipotesiskan. Evaluasi menghasilkan hasil yang baik apabila: 
(1) koefisien hubungan antar variabel tersebut signifikan secara statistik (t-statistik $\geq 1,96)$; (2) nilai koefisien determinasi $\left(\mathrm{R}^{2}\right)$ mendekati 1 . Nilai $\mathrm{R}^{2}$ menjelaskan seberapa besar variabel eksogen yang dihipotesiskan dalam persamaan mampu menerangkan variabel endogen. Dimana, $\mathrm{R}^{2} \geq 0.90$ menunjukkan close fit, $0.70 \geq$ $\mathrm{R}^{2} \geq 0.90$ menunjukkan good fit dan $\mathrm{R}^{2} \leq 0.70$ menunjukkan model yang kurang fit. Hubungan-hubungan kausal ini dapat dirangkum pada tabel 3.

Tabel 3. Hubungan antar Path Diagram dan Uji Signifikansi

\begin{tabular}{clccc}
\hline No. & \multicolumn{1}{c}{ Path (Lintasan) } & $\begin{array}{c}\text { P-Value } \\
(>\mathbf{0 , 0 5})\end{array}$ & $\begin{array}{c}\text { T-Value } \\
(>\mathbf{1 , 9 6 )}\end{array}$ & Kesimpulan \\
\hline 1 & Culture $\rightarrow$ Commitment & 0,45 & 4,87 & Signifikan \\
\hline 2 & Culture $\rightarrow$ Satisfaction & 0,28 & 4,15 & Signifikan \\
\hline 3 & Culture $\rightarrow$ Performance & 0,44 & 4,70 & Signifikan \\
\hline 4 & Leadership $\rightarrow$ Commitment & 0,62 & 6,23 & Signifikan \\
\hline 5 & Leadership $\rightarrow$ Satisfaction & 0,75 & 8,31 & Signifikan \\
\hline 6 & Leadership $\rightarrow$ Performance & 0,05 & 0,34 & Tidak Signifikan \\
\hline 7 & Commitment $\rightarrow$ Performance & 0,017 & 0,15 & Tidak Signifikan \\
\hline 8 & Satisfaction $\rightarrow$ Performance & 0,59 & 4,67 & Signifikan \\
\hline
\end{tabular}

Sumber: data diolah
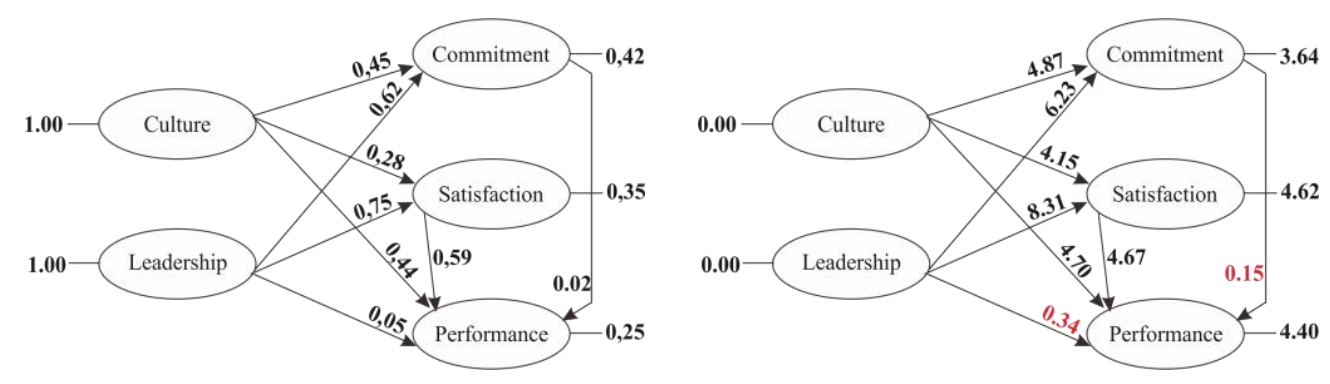

Sumber: Data diolah.

Gambar 2. Perbandingan Hasil Estimasi Akhir Full Model Solusi Standar (Kiri) dan Uji T (Kanan).

Gambar 2 menunjukkan bahwa terdapat dua path dinyatakan tidak signifikan, yaitu leadership $\rightarrow$ performance dan commitment $\rightarrow$ performance. Sedangkan enam path lainnya dinyatakan signifikan, antara lain culture $\rightarrow$ commitment, culture $\rightarrow$ satisfaction, culture $\rightarrow$ performance, leadership $\rightarrow$ commitment, leadership $\rightarrow$ satisfaction, dan satisfaction $\rightarrow$ performance.

Untuk koefisien determinan $\left(\mathrm{R}^{2}\right)$ yang akan digunakan adalah nilai dari reduce form equation, persamaannya adalah sebagai berikut: (1) commitme = $0.45 *$ culture $+0.62 *$ leadersh, errorvar $=0.42, \mathrm{R}^{2}=0.58$; (2) satisfac $=$ $0.28 *$ culture $+0.75 *$ leadersh, errorvar $=0.35, \mathrm{R}^{2}=0.65$ dan (3) performa $=$ $0.017 *$ commitme $+0.59 *$ satisfac $+0.44 *$ culture $+0.046 *$ leadersh, errorvar. $=$ $0.25, \mathrm{R}^{2}=0.75$.

Kesimpulan yang dapat diambil dari model persamaan diatas yaitu: (1) $R^{2}$ : 0,58 yang menunjukkan bahwa variasi pada culture dan leadership menjelaskan 
$58 \%$ variasi dari commitment, sementara sisanya sebesar $0,42(42 \%)$ berupa error dijelaskan oleh variabel lain; (2) $\mathrm{R}^{2}$ : 0,65 yang menunjukkan bahwa variasi pada culture dan leadership menjelaskan $65 \%$ variasi dari satisfaction, sementara sisanya sebesar $0,35(35 \%)$ berupa error dijelaskan oleh variabel lain serta (3) $R^{2}$ : 0,75 yang menunjukkan bahwa variasi pada commitment, satisfaction, culture dan leadership menjelaskan $75 \%$ variasi dari commitment, sementara sisanya sebesar $0,25(25 \%)$ berupa error dijelaskan oleh variabel lain.

\section{Analisis}

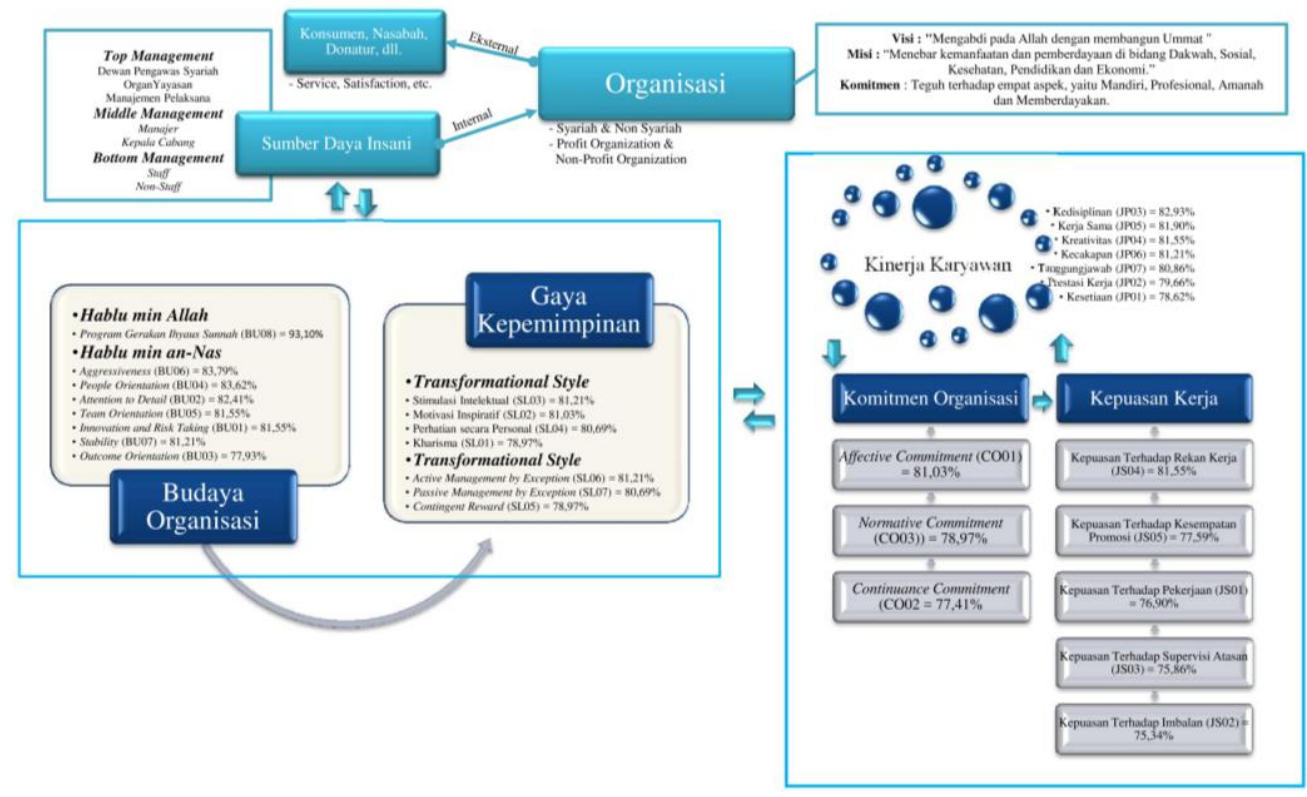

Sumber: data diolah

Gambar 3. Ikhtisar Penelitian

Hasil analisis desktriptif dari penelitian ini menunjukkan bahwa budaya organisasi di Yayasan Nurul Hayat berada pada kategori "sangat baik", sebesar 83,15\% dapat diterima oleh karyawan. Hal ini ditunjukkan pula melalui nilai SFL tertinggi pada variabel budaya organisasi yakni indikator BU07 (stability) sebesar 12,27 dan BU05 (team orientation) sebesar 12,26. Hal ini menunjukkan validitas data pada proses organisasi dalam menghadapi tuntutan manajerial dimana periodesasi sekarang lebih dituntut untuk mengukur kinerja organisasi dan berkontribusi pada stabilitas organisasi dalam lingkungan persaingan saat ini (Iveta, 2012, 2). Stabilitas tersebut akan terbentuk melalui kerjasama tim dimana aturan sosial atas sikap individualisme yang tinggi akan menjalin jalur komunikasi dan kekompakan karyawan satu sama lain dengan pencapaian hasil akhir (Carland, 2008, 63). Selain itu pula kategori usia pada profil responden mendukung variabel budaya organisasi karena sebanyak $62,93 \%$ berusia pada $25-$ 34 tahun yang tegolong usia produktif. Manajemen Nurul Hayat dapat meneruskan upaya Program Gerakan Ihyaus Sunnah sesuai visi NH, "Mengabdi 
pada Allah dengan Membangun Ummat”. Sebanyak 93,10\%, program ini dapat diterima dengan sangat baik oleh karyawan, dan dapat dijadikan budaya organisasi pada karyawan Yayasan Nurul Hayat. Misi NH adalah "Menebar kemanfaatan dan pemberdayaan di bidang Dakwah, Sosial, Kesehatan, Pendidikan dan Ekonomi”, dapat mengubah paradigma kepada stakeholder yang berada dalam naungan manajemen terhadap hablu min Allah dan hablu min an-nas (keluarga, rekan kerja \& orang lain).

Hasil analisis deskriptif dari penelitian ini menunjukkan bahwa gaya kepemimpinan berupa transformasional-transaksional di Yayasan Nurul Hayat berada pada kategori "sangat baik", sebesar 80,39\% dapat diterima oleh karyawan. Hal ini ditunjukkan pula melalui Nilai SFL tertinggi pada variabel gaya kepemimpinan yakni indikator SL07 (Passive Management by Exception) sebesar 11,14 dan SL06 (active management by exception) sebesar 10,72. Hal ini menunjukkan validitas data pada pimpinan perusahaan berusaha untuk memberikan peran dalam proses kerja melalui aturan dan prosedur kerja karyawan (Memon, 2014, 68). Hal ini menunjukkan pula bahwa gaya kepemimpinan pada Yayasan Nurul Hayat lebih dominan mengarah pada gaya kepemimpinan transaksional dimana setiap pekerjaan yang dikerjakan memenuhi syarat SOP, karyawan akan menerima imbalan sesuai target yang diberikan. Hijrah yang dilakukan seorang karyawan menjadi calon pemimpin membutuhkan proses jangka panjang sejak dini dimulai dari karyawan masuk ke dalam perusahaan. Dalam meningkatkan gaya kepemimpinan transformasional-transaksional, manajemen dapat mengupayakan untuk mengadakan leadership training dan gathering untuk lebih meningkatkan karyawan menjadi seorang calon insan yang madani.

Hasil analisis deskriptif dari penelitian ini menunjukkan bahwa kepuasan karyawan di Yayasan Nurul Hayat berada pada kategori "baik", sebesar 77,45\% dapat diterima oleh karyawan. Hal ini ditunjukkan pula melalui Nilai SFL tertinggi pada variabel kepuasan karyawan yakni indikator JS03 (kepuasan terhadap supervisi atasan) sebesar 10,27. Hal ini menunjukkan validitas data pada proses organisasi pekerja magang, staff, dan supervisi akan meraih kepuasan melalui budaya proses kerja yang dialami terlebih dengan menerima gaji, rekan kerja yang profesional hingga promosi posisi pekerjaan yang akan diterimanya (Suma \& Lesha, 2013). Meski prosentase penilaian variabel kepuasan dinilai rendah dari variabel lainnya, sebagai karyawan social/non-profit organization tentunya menginginkan added value atas hasil kerja yang diberikan. Manajemen dapat lebih meningkatkan jenis usaha yang lebih bervariasi untuk meningkatkan motivasi karyawan dan memiliki kepuasan saat bekerja. Hal ini dapat dijumpai dengan semakin bertambahnya kantor cabang yang memiliki peluang untuk memperluas nilai jual dari unit usaha/jasa yang diberikan. Selain itu manajemen 
dapat memberikan penghargaan kepada karyawan berprestasi dan dapat pula saling mempererat hubungan antar divisi dalam perusahaan.

Hasil analisis deskriptif dari penelitian ini menunjukkan bahwa komitmen organisasi di Yayasan Nurul Hayat berada pada kategori "baik", sebesar 79,14\% dapat diterima oleh karyawan. Hal ini ditunjukkan pula melalui Nilai SFL tertinggi pada variabel komitmen organisasi yakni indikator $\mathrm{CO} 03$ (normative commitment) sebesar 7,28. Hal ini menunjukkan bahwa validitas data pada proses organisasi dalam meningkatkan kinerja, perusahaan dapat melakukan stimulan terhadap komitmen organisasi sehingga terdorong produktivitas yang tinggi (Khan, et.al., 2010, 296). Hal ini menunjukkan bahwa komitmen organisasi pada Yayasan Nurul Hayat lebih dominan mengarah pada normative commitment dimana setiap karyawan merasa dengan bekerja di lembaga sosial akan memperoleh nilai-nilai agama dan moral lebih, dengan harapan meraih jenjang karir dan loyal kepada perusahaan. Implikasi yang dapat diberikan adalah manajemen dapat memberikan motivasi dan pengarahan agar setiap karyawan merasa memiliki perusahaan dan dapat menimbulkan komitmen tinggi untuk mencapai tujuan bersama. Lingkungan kerja yang baik akan membuat karyawan merasa nyaman dan dapat meningkatkan kinerja di perusahaan.

Hasil analisis deskriptif dari penelitian ini menunjukkan bahwa kinerja karyawan di Yayasan Nurul Hayat berada pada kategori "sangat baik", sebesar 80,96\% dapat diterima oleh karyawan. Hal ini ditunjukkan pula melalui Nilai SFL tertinggi pada variabel komitmen organisasi yakni indikator JP03 (Kedisiplinan) dan JP04 (Kreativitas) sebesar 10,85. Hal ini menunjukkan validitas data pada kinerja karyawan dapat terjalin dengan baik apabila perusahaan mampu menciptakan suasana kedisipilinan yang mampu berdampak pada tingkat efisiensi dan efektivitas kerja, sehingga karyawan dapat mengeksplorasikan melalui target kerja masing-masing (Sarwani, 2016, 54). Dengan karyawan yang cenderung tergolong dalam usia produktif (25-34 tahun) yang lebih cenderung kreatif dan produktif, hingga kini Yayasan Nurul Hayat telah membuka 22 kantor cabang di Indonesia dan mampu berkontribusi pada program sosial dan dakwah dimana gaji karyawan 100\% murni dari unit usaha kemandirian yang dijalankan. Namun manajemen dapat mengevaluasi kembali, kinerja karyawan dikarenakan indikator "prestasi kerja" memiliki score yang paling rendah diantara indikator yang lain. Implimentasi yang dapat dilakukan manajemen untuk lebih meningkatkan kinerja diantara lain dapat meningkatkan tantangan pekerjaan dari level sebelumnya seperti rotasi, perbaikan skill hingga menciptakan passion karyawan tersebut agar suasana lingkungan kerja tidak terlalu monoton.

\section{Pembahasan}

Budaya organisasi berpengaruh terhadap komitmen organisasi. Berdasarkan hipotesis ini, budaya organisasi mempunyai pengaruh positif dan signifikan 
terhadap komitmen organisasi. Hal ini menunjukkan bahwa budaya organisasi berpengaruh terhadap kinerja karyawan hasilnya diterima, yang berarti dengan adanya penerapan budaya organisasi dapat meningkatkan komitmen organisasi Yayasan Nurul Hayat.

Hasil ini menegaskan bahwa budaya organisasi merupakan salah satu penentu penting pada lingkungan kerja yang baik dalam memotivasi karyawan dalam mencapai komitmen penuh mereka untuk kesuksesan organisasional, hal serupa dengan hasil penelitian Zain, et.al. (2009) dan Rashid, et.al. (2003). Hasil ini menunjukkan bahwa adanya lingkungan persaingan antar organisasi, sangat penting bagi organisasi untuk menciptakan kebijakan yang sesuai bagi karyawannya untuk membentuk komitmen yang kuat di antara mereka (Shoaib, et.al., 2013)

Budaya organisasi berpengaruh terhadap kepuasan kerja. Berdasarkan hipotesis ini, budaya organisasi mempunyai pengaruh positif dan signifikan terhadap kepuasan kerja. Hal ini menunjukkan bahwa budaya organisasi berpengaruh terhadap kepuasan kerja hasilnya diterima. Hal ini memiliki arti bahwa adanya penerapan budaya organisasi dapat meningkatkan kepuasan kerja di Yayasan Nurul Hayat.

Hasil ini menegaskan bahwa mayoritas karyawan lebih suka bekerja di lingkungan yang lebih bersahabat, saling percaya dan hubungan informal di antara rekan kerja dimana dapat menghasilkan tingkat kepuasan kerja karyawan melalui budaya organisasi yang berada dalam perusahaan (Belias, et.al., 2014). Dalam penelitian lain juga menegaskan dimana adanya sifat organisasi berpengaruh secara signifikan terhadap Kepuasan Kerja dan tujuan menurunkan adanya turnover (Habib, et.al., 2014).

Budaya organisasi berpengaruh terhadap kinerja karyawan. Berdasarkan hipotesis ini, budaya organisasi mempunyai pengaruh positif dan signifikan terhadap kinerja karyawan. Hal ini menunjukkan bahwa budaya organisasi berpengaruh terhadap kinerja karyawan hasilnya diterima, yang berarti dengan adanya penerapan budaya organisasi dapat meningkatkan kinerja karyawan Yayasan Nurul Hayat.

Hasil ini menegaskan bahwa dimensi budaya tertentu telah diidentifikasi melalui beberapa penelitian. Hal ini terkait dengan tujuan sebuah organisasi, yaitu untuk meningkatkan tingkat kinerja dimana sistem manajemen kinerja telah diukur dengan balanced scorecard dengan memahami sifat dan kemampuan budaya pada suatu organisasi (Awadh \& Saad. 2013). Dalam penelitian lain juga menegaskan adanya budaya organisasi dengan mengadakan kegiatan ritualitas dalam organisasi memiliki dampak positif dan besar terhadap kinerja karyawan (Paschal \& Nizam, 2016).

Gaya kepemimpinan berpengaruh terhadap komitmen organisasi. Berdasarkan hipotesis ini, gaya kepemimpinan mempunyai pengaruh positif dan 
signifikan terhadap komitmen organisasi. Hal ini menunjukkan bahwa gaya kepemimpinan berpengaruh terhadap komitmen organisasi hasilnya diterima, yang berarti dengan adanya penerapan gaya kepemimpinan dapat meningkatkan komitmen organisasi Yayasan Nurul Hayat.

Hasil ini menegaskan bahwa pimpinan dengan kecerdasan emosional tinggi dapat mengubah arah hubungan antara gaya kepemimpinan transformasionaltransaksional terhadap komitmen organisasi menjadi manajemen yang lebih baik (Alkhatani, 2015). Dalam penelitian lain juga menegaskan bahwa terdapat hubungan positif dan signifikan antara gaya kepemimpinan dan komitmen organisasi, dimana kepemimpinan transformasional memiliki peran positif dan lebih puas dengan pekerjaan karyawan yang menyukai adanya penghargaan dan motivasi oleh perusahaan untuk meningkatkan komitmen terhadap organisasi (Mahmood, 2015).

Gaya kepemimpinan berpengaruh terhadap kepuasan kerja. Berdasarkan hipotesis ini, gaya kepemimpinan mempunyai pengaruh positif dan signifikan terhadap kepuasan kerja. Hal ini menunjukkan bahwa gaya kepemimpinan berpengaruh terhadap kepuasan kerja hasilnya diterima, yang berarti dengan adanya penerapan gaya kepemimpinan dapat meningkatkan kepuasan kerja Yayasan Nurul Hayat.

Hasil ini menegaskan adanya dua jenis gaya kepemimpinan, yaitu transaksional dan transformasional ternyata memiliki hubungan langsung dengan kepuasan kerja karyawan dimana gaya kepemimpinan transformasional memiliki hubungan yang lebih kuat dengan kepuasan kerja. (Voon, et.al. 2011). Dalam penelitian lain juga menegaskan pada pelayanan perawat untuk meningkatkan kualitas layanan perawatan kesehatan di Malaysia menghasilkan adanya gaya kepemimpinan transformasional memiliki kontribusi lebih terhadap kepuasan kerja dibandingkan dengan gaya kepemimpinan transaksional (Ahmad, et.al., 2013).

Gaya kepemimpinan berpengaruh terhadap kinerja karyawan. Berdasarkan hipotesis ini, gaya kepemimpinan mempunyai pengaruh positif dan tidak signifikan terhadap kinerja karyawan. Hal ini menunjukkan bahwa gaya kepemimpinan berpengaruh terhadap kinerja karyawan hasilnya ditolak. Yang berarti bahwa pemimpin dengan indikator gaya kepemimpinan yang diberikan pada penelitian tidak dapat menghasilkan kinerja karyawan secara memadai dan cenderung lebih rendah.

Hal ini berbeda dengan penelitian terdahulu yang digunakan pada Mariam (2009) di mana pengaruh gaya kepemimpinan terhadap kinerja pegawai adalah signifikan dan positif. Dalam penelitian lain menegaskan dalam hasil yang sama dimana komitmen berorganisasi ditemukan berhubungan secara signifikan dengan kepuasan kerja, namun tidak dengan kinerja karyawan (Yiing \& Kamarul, 2008; Handoyo, et.al., 2015). Temuan ini menunjukkan efek negatif bahwa apa yang 
dilakukan pemimpin secara langsung tidak akan mempengaruhi kinerja karyawan, namun karyawan memiliki kepuasan kerja. Berdasarkan penelitian ini menunjukkan jenis gaya kepemimpinan transformasional-transaksional tidak cukup mampu memperlakukan karyawan NH untuk mencapai kinerja optimal. Sedangkan karyawan cenderung memiliki kepuasan kerja untuk memperoleh imbalan (upah) kerjanya dengan gaya kepemimpinan yang diberikan.

Komitmen organisasi berpengaruh terhadap kinerja karyawan. Berdasarkan hipotesis ini, komitmen organisasi mempunyai pengaruh positif dan tidak signifikan terhadap kinerja karyawan. Hal ini menunjukkan bahwa komitmen organisasi dapat berpengaruh kinerja karyawan hasilnya ditolak. Yang berarti bahwa indikator komitmen organisasi dengan yang diberikan pada penelitian tidak dapat meningkatkan kinerja karyawan.

Penelitian terdahulu mendukung temuan penelitian ini yang dilakukan oleh Yiing \& Kamarul (2008), menunjukkan bahwa pada Komitmen organisasi secara signifikan berhubungan dengan kepuasan kerja, tapi tidak dengan kinerja karyawan. Dalam temuan lain juga menyebutkan bahwa komitmen organisasi tidak berpengaruh signifikan terhadap kinerja karyawan (Wibowo, 2014; Renyut, et.al. 2017). Komitmen yang dimiliki oleh karyawan NH belum berorientasi pada pencapaian pekerjaan yang meliput kuantitas \& kualitas pekerjaan, ketepatan waktu pekerjaan hingga biaya yang diperhitungkan dalam penyelesaian pekerjaan.

Kepuasan kerja berpengaruh terhadap kinerja karyawan. Berdasarkan hipotesis H8, kepuasan kerja mempunyai pengaruh positif dan signifikan terhadap kinerja karyawan. Hal ini menunjukkan bahwa kepuasan kerja berpengaruh terhadap kinerja karyawan hasilnya diterima, artinya dengan adanya kepuasan kerja dapat meningkatkan kinerja karyawan Yayasan Nurul Hayat. Sedangkan, nilai koefisien pengaruh kepuasan kerja terhadap kinerja karyawan meningkat sebesar 1\%, maka kinerja karyawan Yayasan Nurul Hayat juga akan naik sebesar $0,59 \%$.

Hasil ini menegaskan bahwa adanya kesamaan korelasi positif antara kepuasan kerja dan kinerja karyawan pada supervisor dan pekerja yang bekerja di industri otomotif. (Shaju, 2016). Penelitian lain juga menunjukkan apabila karyawan memiliki tingkat kepuasan tinggi ketika merasa aman, bebas dari ketegangan dan cenderung lebih loyal terhadap perusahaan dapat berdampak positif dengan kinerjanya kepada perusahaan (Awan \& Asghar, 2014).

\section{KESIMPULAN}

Berdasarkan hasil uraian penelitian serta pembahasan yang telah dilakukan pada bab sebelumnya, maka kesimpulan dari pengaruh budaya organisasi dan gaya kepemimpinan transformasional-transaksional terhadap kinerja karyawan melalui komitmen organisasi dan kepuasan kerja pada Yayasan Nurul Hayat antara lain: (1) budaya organisasi mempunyai pengaruh positif dan signifikan 
terhadap kinerja karyawan, komitmen organisasi dan kepuasan kerja; (2) gaya kepemimpinan mempunyai pengaruh positif dan signifikan terhadap kepuasan kerja dan komitmen organisasi; (3) gaya kepemimpinan mempunyai pengaruh positif dan tidak signifikan terhadap kinerja karyawan; (4) komitmen organisasi mempunyai pengaruh positif dan tidak signifikan terhadap kinerja karyawan dan (5) kepuasan kerja mempunyai pengaruh positif dan signifikan terhadap kinerja karyawan.Implikasi manajerial yang dapat diberikan adalah program Gerakan Ihyaus Sunnah (GIS) sebagai budaya organisasi dapat meningkatkan kinerja karyawan dalam menciptakan suasana kondusif dalam bekerja. Manajemen diharap terus istiqomah dan kreatif dalam mengawal kegiatan positif ini sebagai bagian peningkatan diri terhadap hablu min Allah dan hablu min an-nas (Keluarga, Rekan Kerja \& Orang Lain). Proses adaptasi perlakuan budaya islam memang membutuhkan waktu dan proses kepada karyawan yang belum menjalaninya. Namun budaya islami harus diciptakan pada setiap organisasi bernuansa syariah karena dapat menumbuhkan motivasi bagi karyawan untuk memiliki sifat loyalitas kepada perusahaan. Adapun organisasi konvensional/nonsyariah dapat menyusun program budaya organisasi yang kreatif dan inovatif. Sehingga setiap anggota yang berada di perusahaan memiliki rasa kepuasan tinggi dan tidak berniat untuk meninggalkan perusahaan yang dinaunginya.

Selain itu adakalanya setiap perusahan dapat memiliki ciri khas gaya kepemimpinan masing-masing, namun penulis menyarankan kepada manajemen agar lebih menerapkan model transformasional-transaksional. Model ini adalah proses timbal balik yang terukur bagaimana seorang pemimpin mampu memberikan kontribusi kepada anggota dan perusahaan. Seorang pemimpin dituntut untuk menyusun kebijakan dan alternatif arahan perusahaan sesuai dengan visi dan misi. Untuk mencapai hal tersebut dibutuhkan anggota sebagai pelaku organisasi yang dikaryakan untuk mendapatkan suatu pekerjan hingga memperoleh penghargaan/apresiasi dari perusahaan.

\section{REFERENSI}

Aguinis, Herman. (2011). Performance Management. Edinburgh Business School, PE-AI engb I, 2-27. Edinburgh.

Ahmad, Abd. Rahman; Mohd Nazir Mohd Adi. Haris Md. Rahman Noor; Abdul Ghafar Abdul; \& Tan Yushuang. (2013). "The Influence of Leadership Style on Job Satisfaction among Nurses". Asian Social Science. Vol. 9, No. 9; 2013 ISSN 1911-2017 E-ISSN 1911-2025. doi:10.5539/ass.v9n9p172.

Adekola, Bola. (2012). The Impact of Organizational Commitment on Job Satisfaction: A Study of Employees at Nigerian Universities. International Journal of Human Resource Studies, Vol. 2, No. 2, pp. 1-17. Doi:10.5296/ijhrs.v2i2.1740. 
Alkhatani, Ali Hussein. (2015). "The Influence of Leadership Styles on Organizational Commitment: The Moderating Effect of Emotional Intelligence”. Business and Management Studies. Vol. 2, No. 1; ISSN 23745916 E-ISSN 2374-5924. doi:10.11114/bms.v2i1.1091.

Amstrong, M. A. (2006). Handbook of Human Resource Management. Practice, Tenth Edition, London: Kogan Page Publishing.

Ascarya. (2012). Aplikasi SEM dengan Lisrel.pdf. Disampaikan pada Seminar: Metodologi Penelitian, STEI Tazkia Bogor.

Awadh, Al Harbi Mohammad \& Al Yahya Mohamed Saad. (2013). Impact of Organizational Culture on Employee Performance. IRMB Journal: Vol. 2 Issue. 1. Page 168-175. ISSN: 2306-9007.

Badan Amil Zakat Nasional, Rekapitulasi LAZ Skala Kota. Diakses dalam http://pid.baznas.go.id/laz-skala-kab-kota, 2017.

Baznas.go.id. 2017. Rekapitulasi LAZ Skala Nasional. Diakses dalam http://pid.baznas.go.id/laz-skala-nasional, 2017.

Baznas.go.id. 2017. Rekapitulasi LAZ Skala Provinsi. Diakses dalam http://pid.baznas.go.id/laz-skala-provinsi, 2017.

Bangun, Wilson. (2012). Manajemen Sumber Daya Manusia. Bandung: Erlangga.

Bass, B. M., Avolio, B. J., Jung, D. I., \& Berson, Y. (2003). Predicting Unit Performance By Assessing Transformational And Transactional Leadership. Journal of Applied Psychology, 88(2), 207-218. doi:10.1037/00219010.88.2.207

Belias, Dimitrios. Koustelios, Athanasios. Vairaktarakis, George. Sdrolias, Labros. (2014). Organizational Culture and Job Satisfaction of Greek Banking Institutions. Procedia - Social and Behavioral Sciences 175 ISSN. 1877-0428, 314 - 323. doi: 10.1016/j.sbspro.2015.01.1206

Budiarto, Selly Yohanes. (2004). Komitmen Karyawan Pada Perusahaan Ditinjau Dari Kepemimpinan Transformasional Dan Transaksional. Jurnal Psikologi. Vol. 02 No. 02. 121-140.

Carland, JoAnn C.. (2008). Journal Of Organizational Culture, Communications And Conflict. The Journal of Organizational Culture, Communications and Conflict is owned and published by the DreamCatchers Group, LLC, and printed by Whitney Press, Inc. Volume 12, Number 1. ISSN 1544-0508. 
Convertino, J.G. (2008). A Perspective on Current Human Resource Practices by Human Resource Executives at Institutions of Higher Education. Johnson \& Wales University, Providence.

Dadie, Badhoeg, Camela Ikey. Nugraheni, Rini. (2016). Analisis Pengaruh Komitmen Organisasi Dan Kepemimpinan Terhadap Kinerja Karyawan Dengan Kepuasan Kerja Sebagai Variabel Intervening (Studi Pada PT. Madu Baru Bantul Yogyakarta). Jurnal Studi Manajemen dan Organisasi. 13. $1-13$.

Dartey-Baah, Kwasi. Resilient Leadership: A Transformational-Transactional Leadership Mix. Journal of Global Responsibility Vol. 6 No. 1, 2015 pp. 99 112 ( ) Emerald Group Publishing Limited 2041-2568 DOI: 10.1108/JGR-072014-0026

Durkin, Mark, 1999, Employee Commitment in Retail Banking: Identifying and Exploring Hidden Dangers, International Journal of Bank Marketing, Vol 17. 3: 124-134.

Fahmi, Abu. Siswanto, Agus. Farid, Muhammad Fahri. Arijulmanan. (2014). HRD Syariah; Teori dan Implementasi: Manajemen Sumber Daya Manusia Berbasis Syariah. Jakarta: PT. Gramedia Pustaka Utama.

Gharib, Moaz Nagib. Jamil, Syed Ahsan, Ahmad, Moinuddin, Ghouse, Suhail M. (2016). The Impact of Job Stress on Job Performance: A Case Study on Academic Staff at Dhofar University. International Journal of Economic Research (IJER), (C) Serials Publications 13(1), pp. 21-33, ISSN: 0972-9380.

Habib, Salman. Aslam, Saira. Hussain, Amjad. Yasmeen, Sana. Ibrahim, Muhammad. (2014). The Impact of Organizational Culture on Job Satisfaction, Employess Commitment and Turn over Intention. Horizon Research Publishing, 2(6): 215-222, DOI: 10.13189/aeb.2014.020601.

Hoque, Nazamul. Khan, Mohammad Aktaruzzaman. Mowla, Md. Masrurul. (2013). Organisational Culture: Features and Framework from Islamic Perspective. Humanomics. Vol. 29 Issue: 3. pp.202-219

Iveta, Gabčanová. Human Resources Key Performance Indicators. (2012). Vol. 4, Issue 1, pp. 117-128, March 2012. ISSN 1804-171X (Print), ISSN 18041728 (On-line), DOI: 10.7441/joc.2012.01.09J 
Janićijević, Nebojša. (2013). The Mutual Impact Of Organizational Culture And Structure. Economic Annals, Vol. LVIII, No. 198 / July - September 2013 UDC: 3.33 ISSN: 0013-3264.

Jamal, Abu Doleh. (2000), The Jordanian Financial and Manufacturing Human Resource Managers: A Profile. Al-Manarah, Vol. 6, pp. 57-76.

Khan, Muhamad Riaz. Ziaudin. Jam, Farouq Ahmed. Ramay, M. I. The Impacts of Organizational Commitment on Employee Job Performance. European Journal of Social Sciences - Volume 15, Number 3 (2010)

Handoyo, Laura Natalia. Hamid, Djamhur. Iqbal, M. (2015). The Influence Of Leadership Styles On Employee's Performance Through Work Motivation; (An Organizational Study at Four Hotels in Malang). Jurnal Administrasi Bisnis (JAB), Brawiajaya University, Malang, Vol. 22 No. 1.

Mahmood, Amna. (2015). Effects of Leadership styles on Organizational commitment in Public and Private sectors of Pakistan. University of Adger: Thesis, School Business and Law.

Mangkunegara, Anwar Prabu. (2013). Manajemen Sumber Daya Manusia Perusahaan. Bandung: PT. Remaja Rosdakarya.

Mariam, Rani. 2009. Pengaruh Gaya Kepemimpinan Dan Budaya Organisasi Terhadap Kinerja Karyawan Melalui Kepuasan Kerja Karyawan Sebagai Variabel Intervening Studi Pada Kantor Pusat PT.Asuransi Jasa Indonesia (Persero). Tesis. Universitas Diponegoro Semarang.

Masrifah, Atika R. (2017). Aplikasi Structural Equation Modeling (SEM) Menggunakan Lisrel 8.7. Seminar: TheTraining Series; SEM, disampaikan di STEI Tazkia Sentul City Bogor pada 15 April 2017.Mathis, Robert L, \& Jackson, John H. (2011). Human Resource Management. Jakarta: Salemba Empat.

McCloskey, M.W. (2015). What is Transformational Leadership?. http://people.bethel.edu/?pferris/otcommon/TransformationalLeadership.pdf. Diakses pada 15 Juni 2014.

Memon, Khalid Rasheed. (2014). Effects of Leadership Styles on Employee Performance: Integrating the Mediating Role of Culture, Gender and Moderating Role of Communication. International Journal of Management Sciences and Business Research, 2014 ISSN (2226-8235) Vol-3, Issue 7. 
Mondiani, Tria. (2014). "Pengaruh Kepemimpinan Transformasional dan Kompensasi Terhadap Kinerja Karyawan PT. PLN (Persero) UPJ Semarang”. Jurnal Admisitrasi Bisnis. Vol. 1, No. 1. 46-54.

Mowday, R.T., Porter, L.W., and Steers, R.M. (1982). Employee-organization linkages: The Psychology of Commitment, Absenteeism, and Turnover. New York: Academic Press.

Ngadiman, Eliyana, A. and Ratmawati, D. (2013), "Influence of Transformational Leadership and Organisation Climate to The Work Satisfaction, Organisational Commitment and Organisational Citizenship Behaviour on The Educational Personnel of Sebelas Maret University Surakarta. European Journal of Business and Management. ISSN 2222-1905 (Paper) ISSN 22222839 (Online) Vol.5, No.10, 2013

Noordin, Fauziah. Abdul Rahim, Abdul Rahman. Ibrahim, Abu Hasan. Omar, Mohd. Shukri. (1972). An Analysis Of Career Stages On Organisational Commitment Of Australian Managers. International Journal of Business and Social Science. 2,17.117-126.

Odumeru, James A., Ifeanyi, George Ogbonna. (2013). Transformational vs. Transactional Leadership Theories: Evidence in Literature. Dari International Review of Management and Business Research ISSN: 23069007. Vol. 2 Issue. 2

Otoritas Jasa Keuangan. Statistik Perbankan Syariah Agustus 2017, Diakses dalam http://www.ojk.go.id/id/kanal/syariah/data-dan-statistik/statistikperbankan-syariah/default.aspx, 2017.

OJK. 2017. Statistik IKNB Syariah Periode Agustus 2017 diakses dalam http://www.ojk.go.id/id/kanal/syariah/data-dan-statistik/iknbsyariah/Pages/Statistik-IKNB-Syariah-Periode-Agustus-2017.aspx

Ovidiu-Iliuta, Dobre. (2014). The Link between Organizational Culture and Performance Management Practices a Case of it Companies from Romania. The Bucharest University of Economic Studies (Institute of Doctoral Studies, Business Administration, Bucharest, Rumania). 1156-1163.

Paschal, Anozie Obinna. Nizam, Ismail. Effects of Organisational Culture on Employees Performance: Case of Singapore Telecommunication. International Journal of Accounting \& Business Management ISSN: 22894519. Vol. 4 No. 1. DOI: 10.24924/ijabm/2016.04/v4.iss1/19.26. 
Penn, Allisen. (2015). Leadership Theory Simplified, University of Arkansas, United States Department of Agriculture, and County Governments Cooperating, diakses di www.uaex.edu/publications/PDF/FSPSD200.pdf pada 14 Oktober 2018).

Petrescu, A. and Simmons, R. (2008), Human resource management practices and workers' job satisfactions, International Journal of Manpower, Vol. 29, pp. 651-667.

Puspitawati, Ni Made Dwi. (2013). Kepuasan Kerja Dan Komitmen Organisasional: Pengaruhnya Terhadap Kualitas Layanan Hotel Bali Hyatt Sanur. Tesis. Denpasar: Pascasarjana Universitas Udayana Program Studi Manajemen.

Rashid, Md. Zabid Abdul. Sambasivan, Murali. and Johari, Juliana. (2003). The Influence Of Corporate Culture And Organisational Commitment On Performance. Journal of Management Development, Vol. 22 No. 8, 2003. pp. 708-728. q MCB UP Limited. 0262-1711. DOI $10.1108 / 02621710310487873$

Razali, Ritonga. (n.d.). Kebutuhan Data Ketenagakerjaan Untuk Pembangunan Berkelanjutan. Badan Pusat Statistik. Diakses dari www.ilo.org/wcmsp5/groups/public/@asia/@ robangkok/@ilo.../wcms_3465 99.pdf, 2017.

Renyut, Bernard C. Modding, Basri. Bima, Jobhar. Sukmawati, Siti. (2017). The Effect of Organizational Commitment, Competence on Job Satisfaction and Employees Performance In Maluku Governor's Office. IOSR Journal of Business and Management (IOSR-JBM), Volume 19, Issue 11, DOI: 10.9790/487X-1911031829.

Robbins, Stephen P., \& Timothy A. Judge. (2009). Organizational Behavior.Thirteeth Edition. New Jersey: Pearson Prentice Hall.

Sarwani. (2016). The Effect Of Work Discipline And Work Environment On The Performance Of Employees. Sinergi, Volume 6, Number 2. ISSN.:20874987.

Schein, E.H. (2004). Organisational Culture and Leadership. Jossey-Bass. San Francisco.

Shaju. (2017). A study on the impact of Job Satisfaction on Job Performance of Employees working in Automobile Industry, Punjab, India. Journal of 
Management Research ISSN 1941-899X Vol. 9, No. 1. doi:10.5296/jmr.v9i1.10420.

Shoaib, Akhtar. Zainab, Naseer. Maqsood, Haider. Sana, Rafiq. Impact of Organizational Culture on Organizational Commitment: A Comparative Study of Public and Private Organizations. Research Journal of Recent Sciences. Vol. 2(5), ISSN 2277-2502.

Silalahi, Ulber. (2010). Metode Penelitian Sosial. Bandung: PT Refika Aditama, Cet. Ke-2.

Squires, J. E., Hoben, M., Linklater, S., Carleton, H. L., Graham, N., \& Estabrooks, C. A. (2015). Job Satisfaction among Care Aides in Residential Long-Term Care: A Systematic Review of Contributing. Hindawi Publishing Corporation. Nursing Research and Practice. Volume 2015, Article ID 157924, 24 pages. http://dx.doi.org/10.1155/2015/157924

Sukmawati, Anggraini. Himawan, Aditya Anwar. (2015). Studi Literatur Dampak Budaya Organisasi Pada Perusahaan Multinasional. Penilaian Efektivitas Human Capital. JEAM. Vol XIV. 61-67.

Suma, Saimir. Lesha, Jonida. (2013). Job Satisfaction And Organizational Commitment: The Case Of Shkodra Municipality. European Scientific Journal Edition vol.9, No.17 ISSN: 1857 - 7881 (Print) e - ISSN 1857- 7431.

Uddin, Mohammad Jasim. Luva, Rumana Huq. \& Hossian, Saad Md. Maroof. (2013). Impact of Organizational Culture on Employee Performance and Productivity: A Case Study of Telecommunication Sector in Bangladesh. International Journal of Business and Management. Vol. 8, No. 2. 63-77

Voon, M.L.. Lo, M.C.. Ngui1, K.S.. Ayob, N.B.. The influence of leadership styles on employees' job satisfaction in public sector organizations in Malaysia. International Journal of Business, Management and Social Sciences, Vol. 2, No. 1, 2011, pp. 24-32.

Wang, C., Yen, C., \& Liu, G. (2015). How intellectual influence $i$ ndivi dual performance: A multi-level perspective. Computers in Human Behavior. Elsevier Science Publishers B. V. Amsterdam, The Netherlands 51(2), pp. 930-937, doi: 10.1016/j.chb.2014.10.044

Warrilow, Stephen. (2009). "Transformational Leadership Theory - The 4th Key Components in Leading Change \& Managin Change. Diakses dari http://ezinearticles.com/?Transformational-Leadership-Theory---The-4-Key- 

dikutip pada 13 Agustus 2009

Wibowo, Danang M. (2014). Effect of Competence, motivation, organizational commitment to employee performance and job satisfaction of education. International Journal of Business and Management, Vol.5, No. 6, June 2014

Wright, R. (2002). Perceptual Dimensions of Performance Appraisal Management Systems in The Eyes of Different Sample Categories. International Journal of Management, Vol. 19, pp. 184-193.

Yiing, Lee Huey. Zaman, Kamarul Bin Ahmad. (2008). The Moderating Effects Of Organizational Culture On The Relationships Between Leadership Behaviour And Organizational Commitment And Between Organizational Commitment And Job Satisfaction And Performance. Leadership \& Organization Development Journal. Vol. 30 Issue: 1. 53-86. doi: 10.1108/01437730910927106.

Yousef, Darwish A. (2001). Islamic Work Ethic-A Moderator Between Organizational Commitment and Job Satisfaction in a Cross Culture Context. Personel Review, Vol. 30 Issue: 2, pp 152-169, htpps://doi.org/10.1108/00483480110380325.

Yukl, Gary A. (2013). Leadership in Organizations, 8th Edition. Diakses dari https://businessksu.files.wordpress.com/2017/02/leadership_in_organizations _8th_edition__yukl_gary_a_.pdf. University of Albany, State University of New York: by Pearson Education, Inc., publishing as Prentice Hall.

Zheng, C. (2009). Keeping Talents for Advancing Service Firms in Asia. Journal of Service Management, Vol. 20, pp. 482-502. 